\title{
Gasless laparoscopy as an alternative surgery procedure for postmenopausal women with comorbid diseases
}

\section{Bezgazowa laparoskopia jako alternatywna metoda operacyjna u kobiet w okresie pomenopauzalnym z wysokim ryzykiem okołooperacyinym}

\author{
Paweł Pawłowicz, Małgorzata Uchman-Musielak, Grzegorz Jakiel
}

Department of Obstetrics and Gynecology of the Medical Centre of Postgraduate Education in Warsaw, Poland; Head of Department: prof. dr hab. n. med. Grzegorz Jakiel

Przegląd Menopauzalny 2012; 5: 353-355

\begin{abstract}
Summary
Numerous postmenopausal women are in a group with pathologies of female reproductive organs demanding operative treatment. Postmenopausal women are also at an increased risk of a number of health conditions. A review of the literature demonstrated that the laparoscopic procedure using the gasless technique should be recommended to all women with cardiopulmonary risks or with contraindications for general anesthesia.
\end{abstract}

Key words: gasless laparoscopy, postmenopausal women, pneumoperitoneum laparoscopy.

\section{Streszczenie}

Liczna grupa kobiet w okresie pomenopauzalnym wymaga interwencji chirurgicznej z powodu schorzeń narządu rodnego. U kobiet tych występuje także podwyższone ryzyko rozwoju chorób związanych z wiekiem menopauzalnym. Przegląd piśmiennictwa z ostatnich lat wskazuje na procedury operacyjne, które powinny być rekomendowane kobietom ze wspótistniejącą chorobą sercowo-naczyniową lub takim pacjentkom, u których wystąpity przeciwwskazania do znieczulenia ogólnego.

Słowa kluczowe: laparoskopia bezgazowa, kobieta w wieku pomenopauzalnym, laparoskopia z wytworzeniem odmy otrzewnowej.

The laparoscopic procedure was first described by Semm, with the following advantages indicated: minimal invasiveness, less postoperative pain and a shorter recovery period [1]. This technique has been employed broadly for gynecological diseases in many developed countries. However, a laparoscopic paradox is that traditional laparoscopy is a miniinvasive surgical technique that is contraindicated in most compromised women in the postmenopausal age. It increases mainly the risk of cardiovascular disorders and is also connected with a higher risk of postoperative organs insufficiencies. Moreover, laparoscopy causes several pathophysiologic changes such as reduction of the pulmonary function, visceral vasoconstriction, increased dead space, ventilation perfusion mismatch, increase of total peripheral resistance, increased pulmonary wedge pressure, effects on cardiac output and rise in $\mathrm{PaCO}_{2}$. These effects can represent a contraindication to the laparoscopic surgery in women with the cardiorespiratory function. Pneumoperitoneum and Trendelenburg's position have a bad influence on the operation course. Contraindications to laparoscopic procedures in elderly women are intestinal obstruction, huge tumor changes in the abdominal cavity, generalized peritonitis, irreducible hernia, heart insufficiency, recent myocardial infarction, respiratory failure and severe obstructive lung disease. Relative contraindications are many abdominal surgery procedures in the patient's medical history and significant obesity. Usually women in the postmenopausal age are subject to cardiovascular diseases or are at an increased risk of a number of these health conditions. That is why the gasless laparoscopy could be a "gold standard" for postmenopausal women.

In 1993, a new technique, isobaric (gasless) laparoscopic surgery using an abdominal wall-lifting device, was introduced $[2,3]$. The first generation of abdominal 
wall lifting devices provide an intraperitoneal lift. An alternative approach was first described by Hashimoto et al.; abdominal lifting was provided by subcutaneous wires [8]. This concept was then developed with an introduction of new subcutaneous lifting systems for laparoscopic surgery. Gasless laparoscopy using abdominal wall lifting was developed to overcome the adverse effects to pneumoperitoneum, and it has been shown that it does not alter the cardiac function [4]. More importantly, it is possible to perform the surgical procedure under local and regional anesthesia rather than general anesthesia as it has to be done in traditional laparoscopy.

Gasless laparoscopy, with the patient under local and regional (epidural or spinal) anesthesia, can be performed using conventional surgical instruments introduced through small abdominal incisions [7]. It appears to offer several advantages over laparoscopy with pneumoperitoneum. It also enables elimination of the adverse effects and potential risks associated with $\mathrm{CO}_{2}$ insufflations. The benefit of this is also the fact that the peritoneal cavity does not need to be sealed airtight, and conventional long laparotomy instruments, such as tissue clamp, Tenaculum clamps, needle holders, knives, and scissors can be utilized. This facilitates several steps of the procedure. Another advantage is the reduction in operative costs. Expensive, specialized laparoscopic instruments are not needed. In addition, the operating times are decreased because an optimal view can be maintained during irrigation - suction, uterine morcellation by scissors and knives is faster. Therefore, it can represent an excellent option for the minimally invasive surgery in women as an alternative to more aggressive surgery.

However, some criticisms have been made of the gasless laparoscopy. Many gynecologists - laparoscopists are worried about the increased postoperative pain, need for additional abdominal incisions, time required for the assemblage of the abdominal lifting system. But in the recent reports, no patient complained of significant abdominal postoperative discomfort, secondary to the abdominal lifting. The additional suprapubic skin incisions required for the subcutaneous introduction of the 2 curves, needles with the blunt tips of the Laparotenser were very small and needed no suturing [4, 5]. Guido et al. and Sesti et al. reported that the gasless laparoscopic procedure has the same advantages such as decreased postoperative pain [11, 12].

During the pneumoperitoneum laparoscopic procedure, gas loss from the instrument ports and the frequent maneuvering of suction may decrease the space size of the operative field; therefore, the operator must await $\mathrm{CO}_{2}$ re-insufflation to restore the operative space. In the gasless laparoscopic procedure, without the gas leak problem, smoke produced during coagulation or cutting can be sucked continuously to keep the operative field clear. In addition, removal of big solid specimens is always difficult in conventional laparoscopic surgery [6]. In the meantime, large vessels legation can be done by extracorporeal knot-tying, which saves time and avoids severe bleeding during surgery. Damiani et al. reported that there are no differences between the gasless procedures and the traditional laparoscopy as to the indicated intraoperative blood loss [5]. It is important that gasless laparoscopy avoids the derangement of pulmonary mechanics, so it can be performed under local and epidural anesthesia, and therefore decreases the operating room charges.

\section{Conclusions}

Taking into account postmenopausal women with comorbid diseases it is known that gasless laparoscopy has an advantage over conventional laparoscopy, such as shortened hospitalization, smaller incisions and quicker recovery, which is very important for these women.

The established advantages in comparison to traditional laparoscopy are reduced postoperative pain, shorter hospital stay, quicker return to normal activity, increased laparoscopic indications, it is fully physiological, no need of pneumoperitoneum, surgical maneuvers are similar to the laparotomic ones. As concerns conventional laparoscopic surgery, the pneumoperitoneum was established and maintained by constant $\mathrm{CO}_{2}$ insufflation. It brings a series of problems, such as bradyarrhythmias, venous stasis, gas embolism, subcutaneous emphysema and hypercapnia. Gasless laparoscopy, however, is not associated with risks arising from $\mathrm{CO}_{2}$ insufflations. Furthermore, the gasless laparoscopic procedure can also be performed on high-risk patients with poor cardiorespiratory reserve.

Laparoscopic procedures using the gasless technique is a safe, effective method to treat benign gynecological pathologies. Gasless laparoscopy has advantages over pneumoperitoneum laparoscopy, particularly in reducing cardiovascular complications of women in the postmenopausal age. Gasless laparoscopic procedures using the new subcutaneous lifting system is also feasible, reproducible, reliable and safe for postmenopausal women with comorbid disease.

\section{References}

1. Semm K. Tissue-puncher and loop-ligation - new aids for surgical-therapeutic pelviscopy (laparoscopy) $=$ endoscopic intraabdominal surgery. Endoscopy 1978; 10: 119-24.

2. Smith RS, Fry WR, Tsoi EK, et al. Gasless laparoscopy and conventional instruments. The next phase of minimally invasive surgery. Arch Surg 1993; 128: 1102-7.

3. Chin AK, Moll FH, McColl MB, Reich H. Mechanical peritoneal retraction as a replacement for carbon dioxide pneumoperitoneum. J Am Assoc Gynecol Laparosc 1993; 1: 62-6. 
4. Damiani A, Melgrati L, Marziali M, Sesti F. Gasless laparoscopic myomectomy. Indications, surgical technique and advantages of a new procedure for removing uterine leiomyomas. J Reprod Med 2003; 48: 792-8.

5. Damiani A, Melgrati L, Franzoni G, et al. Isobaric gasless laparoscopic myomectomy for removal of large uterine leiomyomas. Surg Endosc 2006; 20: 1406-9.

6. Takeda A, Sakai K, Mitsui T, Nakamura H. Management of large cystic adnexal tumor by gasless laparoscopic-assisted surgery with wound retractor. J Minim Invasive Gynecol 2007; 14: 644-50.

7. Kruschinski D, Homburg S. Lift-(gasless) laparoscopic surgery under regional anesthesia. Surg Technol Int 2005; 14: 193-6.

8. Hashimoto D, Nayeem SA, Kajiwara S, Hoshino T. Abdomina wall lifting with subcutaneous wiring: an experience of 50 cases of laparoscopic cholecystectomy without pneumoperitoneum. Surg Today 1993; 23: 786-90.

9. Kruschinski D, Homburg S, Wöckel A, et al. Lift-laparoscopic total hysterectomy as a routine procedure. Surg Technol Int 2004; 13: 147-56.

10. Sesti F, Capobianco F, Capozzolo T, et al. Isobaric gasless laparoscopy versus minilaparotomy in uterine myomectomy: a randomized trial. Surg Endosc 2008; 22: 917-23.

11. Guido RS, Brooks K, McKenzie R, et al. A randomized, prospective comparison of pain after gasless laparoscopy and traditional laparoscopy. J Am Assoc Gynecol Laparosc 1998; 5: 149-53.

12. Sesti F, Melgrati L, Damiani A, Piccione E. Isobaric (gasless) laparoscopic uterine myomectomy. An overview. Eur J Obstet Gynecol Reprod Biol 2006; 129: 9-14. 